Portland State University

PDXScholar

\title{
Discrimination Against People of Color in America's Cash Bail System
}

Dolores Yanez

Portland State University

Follow this and additional works at: https://pdxscholar.library.pdx.edu/honorstheses

Part of the Civil Rights and Discrimination Commons, Criminal Procedure Commons, and the Criminology and Criminal Justice Commons

Let us know how access to this document benefits you.

Recommended Citation

Yanez, Dolores, "Discrimination Against People of Color in America's Cash Bail System" (2021). University Honors Theses. Paper 964.

https://doi.org/10.15760/honors.987

This Thesis is brought to you for free and open access. It has been accepted for inclusion in University Honors Theses by an authorized administrator of PDXScholar. Please contact us if we can make this document more accessible: pdxscholar@pdx.edu. 


\title{
Discrimination against People of Color in America's Cash Bail System
}

\author{
By:
}

Dolores Yanez

An undergraduate honors thesis submitted in partial fulfillment of the requirements

for the degree of

Bachelor of Criminology and Criminal Justice

Thesis Advisor: Curt Sobolewski

University Honors College

Portland State University

Winter Term 2021 


\section{Table of Contents}

I . Abstract …

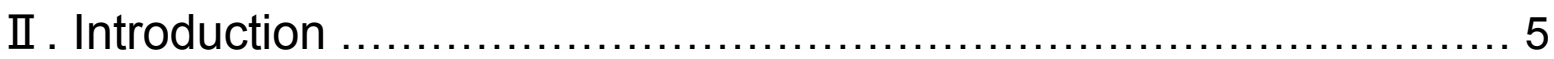

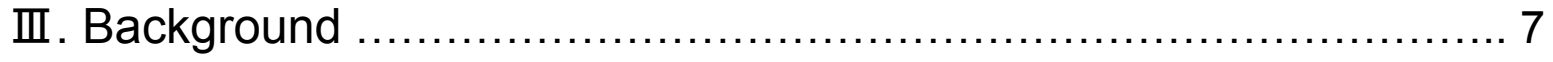

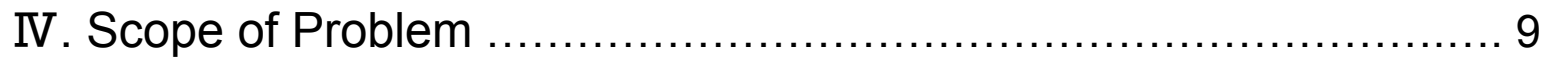

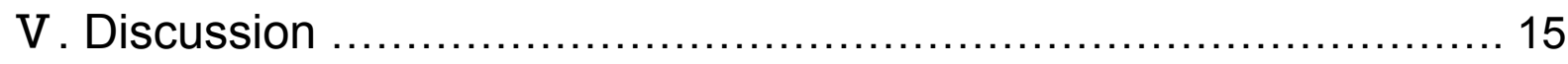

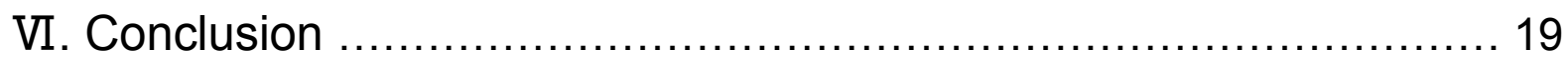

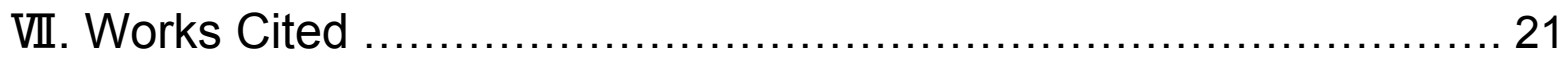


Discrimination against People of Color in America's Cash Bail System

Keywords: Cash Bail, Discrimination, People of Color 


\section{I . Abstract}

The purpose of this thesis is to describe how the current bail system in America is discriminatory and unjust for people of color (POC). The American criminal justice system is represented as a system run by procedural justice, which entails government officials being genuinely concerned about the fairness and transparency of the process by which decisions are made. This presumes that every American will be treated with the same respect and dignity, and that they will be given the same opportunities regardless of their socioeconomic status, racial or ethnic backgrounds. America's cash bail system and its impact on people of color who are incarcerated demonstrates that this is not the case. This thesis highlights those aspects of the cash bail system that make it discriminatory against people of color. 


\section{Introduction}

The disheartening reality is that from the start of the criminal justice journey, POC do not receive the same treatment as other Americans are subjected to. POC are more likely to be under surveillance by police, pulled over, searched, charged with an offence, lack proper representation in court, less likely to get a plea deal and more likely to receive a harsher sentence. This leads to a poor experience between POC and the criminal justice system, which then creates a cycle of miscommunication and maltreatment between both parties. This strained relationship is the reason as to why we have recently seen an uproar in the demand for a reform in the criminal justice system. The bail system is a big contributive factor of the discrimination that POC are subjected to. America's bail system needs to be reformed immediately. It is an immense problem that once dealt with will help to eliminate various other issues within the current criminal justice system. This thesis presents what bail is, how America currently deals with bail, and promising bail initiatives, as well as a discussion for and against the propositions of reformed bail practices.

There are five types of pretrial release mechanisms: release on recognizance, release on citation, cash bail, property bond, and secure bond (Red's, 2020). Cash bail is a process in which the defendant pays a set amount of money in order to be released from custody. This amount of money greatly varies -- it can be as low as $\$ 500$ to as high as millions of dollars. The amount of money set to become bail is at the discretion of the judge who gets appointed to the case. Cash bail was started as a method to "free untried prisoners" while they awaited future court appearances. However, this "for the people" stance initiative has turned sour. Cash bail no longer represents untried 
prisoners; in contrast it is now an immense burden on POC and low-income defendants, this new bail system clearly favors the wealthy and punishes the poor. Despite the countless issues regarding cash bail, it remains the primary mechanism for defendants to obtain pretrial release nationwide (Barno, 2019).

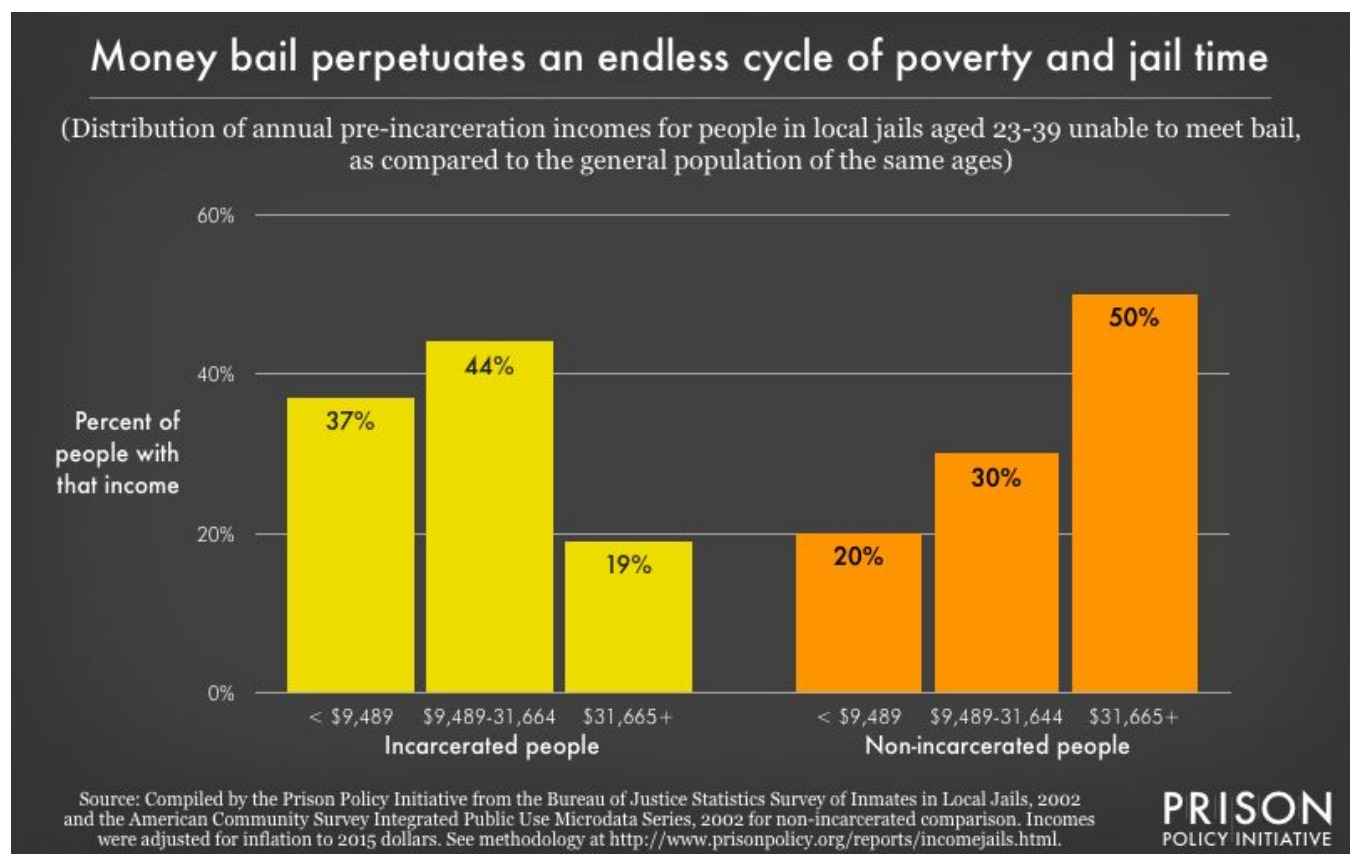

Figure 1: Those who are involved in the criminal justice system tend to also live below the poverty line. The median pre-incarceration income of those in jail makes it clear that the cash bail system is set up for them to fail. Being able to afford the cash bail amount appointed is often impossible for the typical black man and Hispanic woman. Figure 1. Reveals just how unrealistic it is to believe that defendants have a chance of being able to afford typical bail amounts. The median bail bond amount in America is worth eight months of income for the typical detained defendant (Rabuy, 2016). 


\section{Background}

Over the last several years, Black Lives Matter activists have grown collective action around criminal justice reform. More recently in response to the murder of 46-year-old George Floyd, a black man in Minneapolis, Minnesota. Floyd was fatally suffocated by the aggressive and inhumane tactics Officer Chauvin used. Thousands across the country mobilized demanding justice for Floyd, yet Officer Chauvin was still able to pay bail and was released from custody. Chauvin had just been arrested and charged with second degree murder for the wrongful death of Floyd, and through donations he was able to pay his bail, which was set at an enormous amount of a million dollars. If an innocent person of color is forced to sit in jail and await their trial, when on the other hand a guilty white man can walk out of jail after paying a million dollars proves that there is an issue when dealing with the bail system.

America's cash bail system is currently an immense problem. There are hundreds of thousands of people working inside and outside of the system for reform. As a result, states vary in their use of cash bail systems. Oregon, Illinois, Kentucky and Wisconsin approach bail in different ways. For example, in Oregon one can be released by paying $10 \%$ of their set bail. Kentucky banned cash bail 40 years ago, instead of imposing a cash bail amount to decide who gets to go home, they decided to use a risk assessment tool statewide. This risk assessment tool determines who will be released pretrial (Liptak, 2008). California is working towards getting rid of the cash bail system entirely and has decided to do pretrial risk assessments to categorize suspects of low, medium and high risk to help the judge decide if the individual is safe to go home and does not pose a threat to society. However, while some states are actively working to 
reform the cash bail system, the remaining states face immense pressure from people of color to change this unjust system. 


\section{Scope of Problem}

Maranda O'Donnell is a woman who was arrested over some unpaid toll tickets and a suspended license. O'Donell's case is important in this paper because it introduces a number of problems that the innocent face. An innumerable number of Americans who do not pose any real threat to society, end up spending time in jail for the sole reason that they cannot come up with the amount of money required that has been set as their bail. O'Donell is a single mother, who had just moved to Harris County, Texas. She had just started a new job and had no way to come up with her bail amount, therefore she was forced to spend 3 days in jail, leaving her four-year-old daughter. Her experience demonstrates how the cash bail system is discriminatory for POC. Every year, 10 million Americans are taken to jail. Most of them are released, however in any given day jails house over 700,000 people. More than $70 \%$ of those individuals detained have not been convicted of any crime, therefore they are legally presumed innocent. Most of them stay in jail because they simply cannot afford to meet their bail amount. Most are low risk offenders with misdemeanor charges. In 2017, 3 out of 4 inmates could not afford to make bail, which caused them to stay in jail until their trial, in return this cost many of them their jobs, houses and families (Rockett, 2019).

The cash bail system is also discriminatory to POC because black and brown people get arrested more often, get issued bail more often and are often less likely to be able to afford that bail. A 2010 survey of five U.S. cities showed that bail for black defendants is typically $\$ 10,000$ higher than for white defendants. African Americans and Latinos represent $50 \%$ of the U.S pretrial detention population. When people are too poor to pay their way out of jail through bail, they are at risk of losing their jobs, housing 
and their families. Immigrants who are not financially able to pay their bail are also at risk of losing their immigration status and custody of their children.

The problem with the cash bail system not only affects inmates, but the entire community. Texas alone spent a billion dollars on pretrial housing in 2017 , money that could have been better spent on education, roads, housing, healthcare and various other social services. Texas Chief Justice Nathan Hecht realized the great problem that the cash bail system was imposing in Texas and he took it upon himself to reform it. Chief Hecht started by implementing a risk assessment tool to assist judges to better understand the flight risk and danger the inmate imposed on the community if released. It all seemed like a bulletproof plan except it all came crashing down when the bail bondsmen realized how much bail makes them, an annual profit of $\$ 2$ billion. Innocent people should never have to spend a single night in jail simply because they do not have $\$ 500$ dollars, and they should not be declined their right to go home simply because bail companies will lose out on their profit. Judges hold tremendous power in determining who must pay bail, and for how much. They may also be a potential site for leveraging long term change. America should entirely enforce judges to make better calls as to who gets to go home to their families until their day in court, and who truly needs to stay in jail due to the security threat to the community (Butin, 2017). 


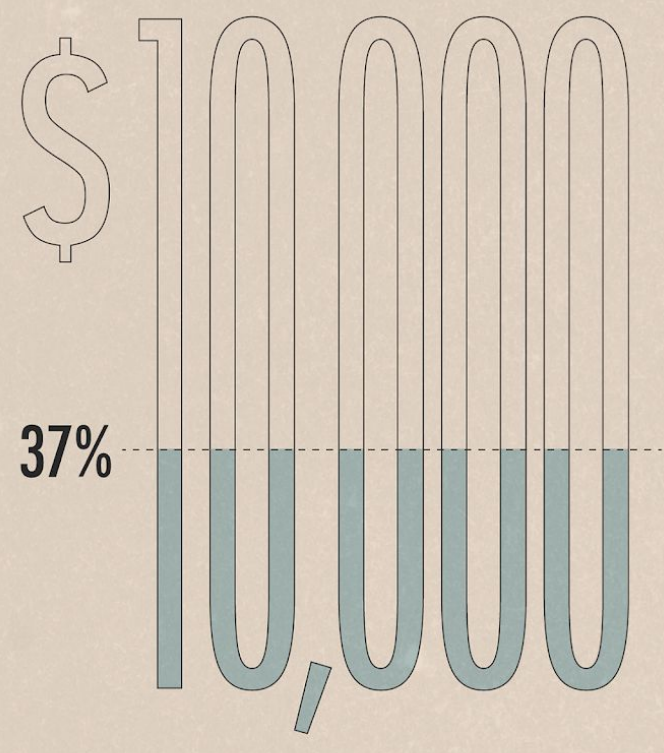

\section{The median cash bail amount is $\$ 10,000$.}

That's more than a full year's income for $37 \%$ of incarcerated people.

Source: Prison Policy Initiative, 2020

Figure 2: Nearly all private bail bondsmen charge fees for their services, a common amount is $10 \%$ of the set bail amount. For example, if a judge sets the bail amount at $\$ 5,000$, the defendant pays a $\$ 500$ fee, which they will not get back regardless if they show up to their court hearing (Wealthsimple, 2020).

As we dive in deeper into the problem that America's cash bail system imposes on POC, it is important to address the bail bond industry as a whole. With the clear notion that the bail bond industry is unregulated and does not align with the policy considerations of bail and pretrial release, immense bail bond amounts grew almost as fast as the amount of those who were unable to pay them. These two problems combined created the American commercial cash bail bond industry. Discriminatory bias stands in the way of POC being eligible to work with bail industries, therefore they must stay in jail and await their day in court. Bail bondsmen have admitted to the fact that they are in this business to make profit and not necessarily concerned with the 
issue they impose on POC, or their unjust administration of justice. This is a huge issue because it takes the power away from judges and courts and is put entirely in the hands of the bail bond industry. Whether someone is innocent and does not pose a threat society matters little when the bail bond industry functions to make profit from imprisonment (Cuasey, 2013).

Four hundred years of genocide and land dispossession means Indigenous people often lack assets themselves nor know anyone that can afford to invest their assets in exchange for their freedom. This creates an issue when it comes to who gets to be released, bail bonds make it close to impossible for POC to get a fair representation in the justice system as the current system discriminates against the poor and working class. POC and low-income individuals have no other choice but to sit in jail and await their trial even though they are low flight risk, and do not pose a threat to society. Seventy percent of inmates in jail are awaiting trial, and most are there not because they are a threat to society but because they cannot afford to make bail (Goff, 2017). They are not violent people, they are low risk of not returning to court for lack of resources, as well as having been arrested for misdemeanor charges.

Wealth based practices are discriminatory because they make it impossible for low-income people who are innocent to go home. Five out of 6 defendants are in jail simply because they could not afford the assigned bail amount (Cohen, 2007). It has now come down to the decision of who's innocent and does not pose a real threat to society, but who has good financial standing. This is a clear burden to the poor and working-class members of society as it creates an ethical issue, and it clearly does not go hand in hand with the constitutional right that everyone gets a fair trial. Defendants 
who are incarcerated pretrial are significantly more likely to be convicted. This is largely because those who can't go home after paying bail to prepare their cases are forced to sit in jail and rely on their family to assist them. Most have little to no legal education or training with how the criminal justice system works making it challenging to hire a good lawyer, and ultimately leads many people to take plea deals which proceeds with millions of POC spending time in jail and often even prison.

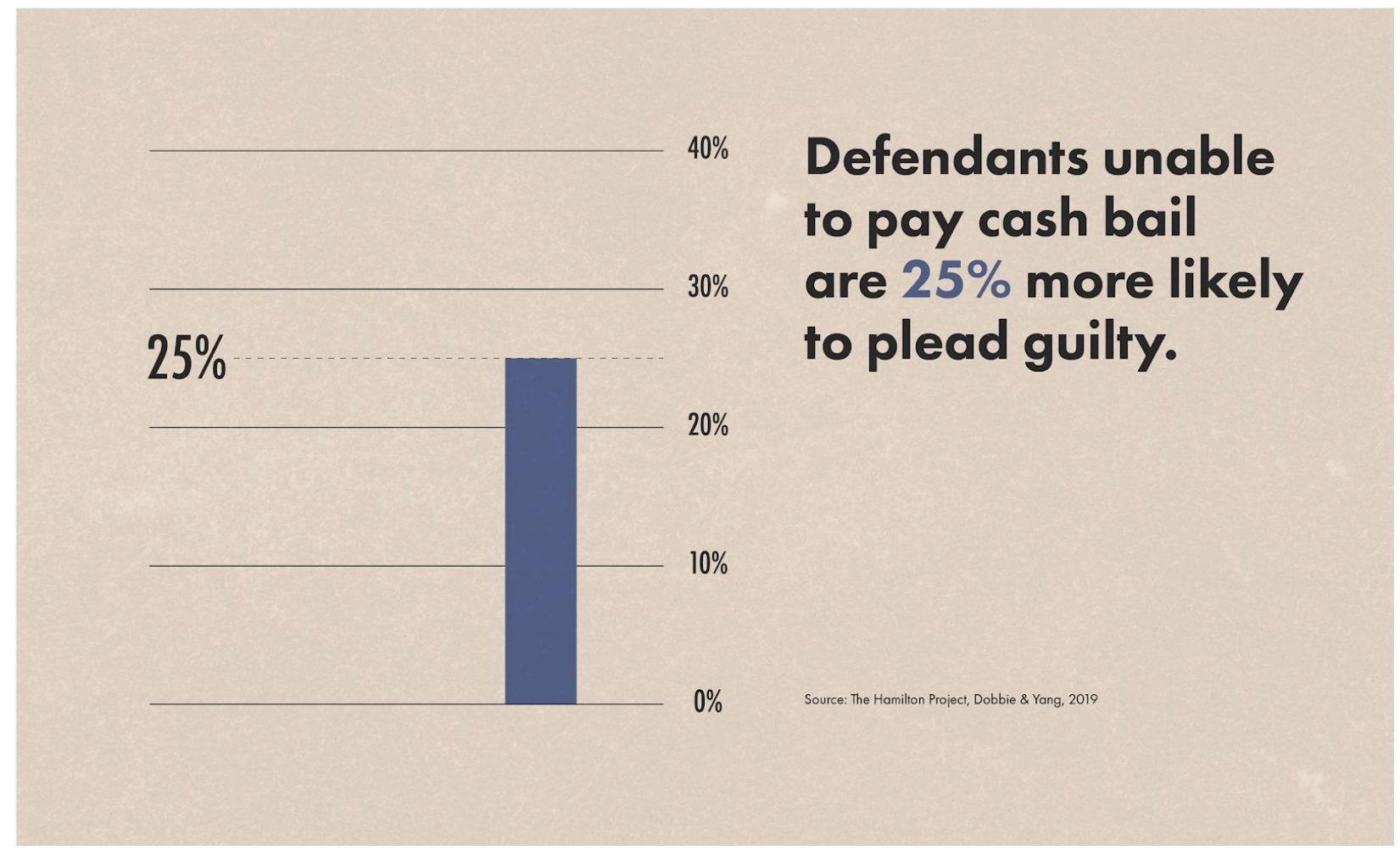

Figure 3: Since most individuals in the criminal justice system live below the poverty line, they often cannot afford a private attorney, and they await trial in jail. Many families have no legal knowledge on the steps to take once in jail, and therefore the defendant has no choice but to await their trial in jail. Defendants who cannot afford bail are ten times more likely to take a guilty plea, too many POC take guilty pleas just so they can get their trial over with and put their time in jail towards their sentence. They do 
this in order to speed up the process, so they go home to their families (Wealthsimple, 2020).

Black and Hispanic men are less likely to be employed compared to white men (Wilson, 2018). Many POC families depend on the little money the man of the household brings in, when these men are arrested and cannot afford to make bail, which results in them being incarcerated and losing more than just their freedom. POC families are left to live below the poverty line, many of those children with incarcerated parents are forced to start working and leave their education behind. Others fall victim to the same cycle that took their loved one. Once these POC men and women are released from jail, they find it more difficult to get jobs and housing, which further puts them at a disadvantage and they make the same mistakes over again, resulting in the endless cycle that has been happening for hundreds of years. Judges should implement the use of personalized diversion programs instead of jail time, however judges are so far behind in their case log due to the high number of arrests that it is almost an impossible task, that's why these risk assessments are so important to implement. 


\section{Discussion}

In the current scholarly conversation regarding the cash bail system there has been contradicting viewpoints, many scholars believe in different types of bail and the ways they should be implemented. Other scholars believe that the bail system should not be used entirely and instead judges should strictly base their decision on algorithm-based risk assessments. For example, judges are now given full power to detain people using algorithm-based risk assessment, which is supposed to help determine who should be released and who shouldn't. However, this approach has been proven to be even more discriminatory as reports say that it will increase the number of those held in pretrial detention and further separate defendants on racial and economic disparities. Activists also worry that by implementing these risk assessments algorithms to help determine defendant flight risk, they will only perpetuate racial discrimination. However, the much-debated use of these risk assessments, studies have found that they have been a great resource for over-worked judges to help clear their backlog of offenders. The risk assessment tools provide two scores, one being the likelihood of the offender committing another offence upon release, and the second score being the probability of that individual coming back for their court hearing. Using these scores, judges are able to make more educated and personalized decisions regarding pretrial release (Carlisle, 2018).

GPS monitoring is becoming a heavily used alternative to cash bail and in 2018 The Bronx Freedom Fund was created. This nonprofit organization helped pay bail for 
New Yorkers who couldn't afford it. This organization operates on a model of harm reduction and helped launch the idea that there are various ways that the city can stay safe without exploiting its people with cash bails. The organization was incredibly successful. They found that even when the defendants' bail was paid for, $96 \%$ of the people made it to their court dates (Laird, 2019). When asked what led to their success it was a simple answer: sending reminders not through bounty hunters but by sending court date reminders via text messages. The use of GPS as another form of bail has also been an option many counties are exploring, for example using ankle monitors on people awaiting their trial. Using GPS monitoring instead of bail will have a lasting effect on society, it will diminish the financial burden bail imposes. Electronic monitoring is extremely promising in the bail reform, as it is an incredible tool to decrease pre-trial detention (Cuasey, 2013).

As previously mentioned, Americans see the criminal justice system as based on procedural justice, which constitutes the principle of presumption of innocence, which states that every American is innocent until proven guilty. However, with the implementation of the cash bail system that philosophy is altered to those who are financially well off. The cash bail system places an immense financial burden on POC because when the system of money bail is the only determining factor whether an individual can be released, pretrial makes it so POC and other minorities have no other option but to await their day in court while sitting in overcrowded jails. POC are notoriously arrested at higher rates, they also make less money than white individuals. The income discrepancy between a white man and a black man is an average of $\$ 7$ USD hourly. Women are at an even bigger disadvantage, in 2018 a woman working full 
time in America earned 81.6 cents for every dollar a man made. This wage difference results in a woman's median annual salary to be $\$ 9,766$ less than the average man (Patten, 2016).

A lot of people will wonder why the government would want to house so many individuals in local jails when pretrial detention costs $\$ 13.6$ billion every year. The answer is simple -- jails have stakeholders that get paid depending on the population of those incarcerated. Prisons are for profit; prisoners and families are nickel and dimed. Jails are also a great source of income for various companies. Families that keep in touch with their incarcerated loved ones understand just how expensive it is. Phone calls between the outside world and jails cost an average of $\$ 1$ a minute (Wagner, 2019). Commissary stores are essential for inmates as that is where they can buy anything from deodorant to the paper they use to write letters to their families. Not only are stakeholders and essential suppliers profitable, so are judges. Many judges have been found guilty of enforcing questionable laws for the sole purpose of growing the inmate population in their county for a personal gain. One example of this horrendous abuse of power is the infamous "Kids for Cash Scandal" of 2009, where Mark Ciavarella, a former president judge who would extend juvenile extension stays in return for financial kickbacks from private for-profit facility owners.

There are ways that the system can reduce the number of arrests that lead to overcrowded jails starting at the time of arrest. For example, turning arrest to citations, enforcing diversion programs instead of jail time, and the necessary end to sending nonaggressive offenders to jail are some great starting points to lowering jail populations. Increasing funding of available and affordable public attorneys, and other 
sorts of indigent criminal defense can be the key element to bring down the enormous, incarcerated population, and the high percentage of plea deal usage. To reduce the inmate population, counties could safely release older defendants, defendants with no previous criminal records, and those who have been charged with public offenses and misdemeanors at no cost of public threat to the general community. Instead of using cash bail, courts can also use other forms of pretrial release such as release on own recognizance which means that the defendant signs and agreement that they will appear at their court date, and using unsecured bonds which unlike cash bail, the defendant is not required to pay any money, they will simply be liable to pay an agreed amount only if they do not appear for court. 


\section{Conclusion}

In this thesis project, I have described how the cash bail bond system in America is discriminatory, and highlighted the problems it creates for POC as well as for low-income and working families. The high stress from being caught in the cash bail system can lead to high suicide rates. The financial strain leads to innocent people awaiting their trial in jail, as well as taking guilty pleas just so they can go home to their family, job and overall, their life. The corrupt way that the bail system is set up in America has led to some of the biggest issues in the criminal justice system (Yang, 2017). Seventy percent of jail populations are there because they can't afford their bail. Most of those incarcerated were arrested for non-violent, misdemeanor crimes, for example, disorderly conduct and probation violations.

Racism and discrimination are not new problems in America. A new generation of civil rights activists working through the Black Lives Matter movement have been organizing day in and day out to wake America up and reform the criminal justice system. Many have woken to the ways in which police have ultimate power to monitor, apprehend, arrest, incarcerate, and kill black people and Indigenous people of all ages. My paper is focused on the bail system, but I must also emphasize the underlying racism that is intertwined in the justice system. POC do not feel well represented in court, they feel the discrimination as early on as before their arrest. The same way that police officers are killing innocent black people, the cash bail system is also responsible for the death of thousands. The immense amount of stress that is created when an innocent person is stuck sitting in jail simply because their financial situation does not 
allow them to make bail has been the reason for multiple suicides. The Civil Rights Corps filed a constitutional civil rights lawsuit against the cash bail system in Texas when 55 people died in the local jails in downtown Houston due to the fact that they were too poor to buy their release before trial. The harsh reality is that the cash bail system is in fact discriminatory as almost half of American households cannot afford to come up with $\$ 400$ in case of an emergency (Karakatsanis, 2019).

There needs to be reform. The criminal justice system is not a business and social economic disparities need to be abolished. Jail should be a place where people have an opportunity to repair the harm they have done (if indeed they are guilty of a crime in the first place). Jail should not be a place to make a profit from under-resourced people. Changing the cash bail system is one step in a better direction. 


\section{Works Cited}

Barno, Matt. (July 29, 2019). Exploring Alternatives to Cash Bail: An Evaluation of Orange County's Pretrial Assessment and Release Supervision (PARS) Program. American Journal of Criminal Justice. Web. Retrieved on November 10, 2020 from https://escholarship.org/content/qt3qz81051/qt3qz81051.pdf

Buntin, John. (October 2017). The Fight to Fix America's Broken Bail System. Governing. Web. Retrieved on February 5, 2021 from https://www.governing.com/topics/public-justice-safety/gov-bail-reform-texas-new-jersey $\underline{. \mathrm{html}}$

Carlisle, Madeleine. (September 21, 2018). The Bail-Reform Tools That Activists Want Abolished. The Atlantic. Web. Retrieved on November 10, 2020 from https://www.theatlantic.com/politics/archive/2018/09/the-bail-reform-tool-that-activists-w ant-abolished/570913/

Causey, Alexis. (September, 2013). Reviving the carefully limited exception: from jail to GPS bail. Faulkner Law Review. Web. Retrieved on February 8, 2021 from https://go-gale-com.proxy.lib.pdx.edu/ps/i.do?p=AONE\&u=s1185784\&id=GALE\%7CA38 $\underline{0750103 \& v=2.1 \& i t=r}$ 
Cohen, Thomas. (November, 2017). Pretrial Release of Felony Defendants in State Courts. U.S Department of Justice. Web. Retrieved on March 3, 2021 from https://www.bjs.gov/content/pub/pdf/prfdsc.pdf

Goff, Liana M. (January 1, 2017). Pricing Justice: the Wasteful Enterprise of America's Bail System. Brooklyn Law Review. Web. Retrieved on February 14, 2021 from http://web.b.ebscohost.com.proxy.lib.pdx.edu/ehost/pdfviewer/pdfviewer?vid=1\&sid=61 98583b-2e2c-411f-b4ee-cf90bcba6d44\%40pdc-v-sessmgr03

Karakatsanis, Alec. (December 16, 2019). Americans Aren't Supposed to Be Jailed Before Trial Just Because They Can't Make Bail. But It Happens All the Time. TIME. Web. Retrieved on June 12, 2021 from https://time.com/5749542/cash-bail-impact/

Laird, Lorelei. (November 1, 2019). The Bail Project pays defendants' bail as part of a plan to end money bail entirely. Abajournal. Web. Retrieved on March 3, 2021 from https://www.abajournal.com/magazine/article/the-bail-project-pays-defendants-bail-as-p art-of-a-plan-to-end-money-bail-entirely

Liptak, Adam. (January 29, 2008). Illegal Globally, Bail for Profit Remains in U.S. The New York Times. Web. Retrieved on March 3, 2021 from https://www.nytimes.com/2008/01/29/us/29bail.html?pagewanted=all\&_r=1 
Patten, Eileen. (July 1, 2016). Racial, gender wage gaps persist in the U.S despite some progress. Pew Research Center. Web. Retrieved on February 9, 2021 from https://www.pewresearch.org/fact-tank/2016/07/01/racial-gender-wage-gaps-persist-in-u -s-despite-some-progress/

Rabuy, Bernadette. (May 10, 2016). Detaining the Poor: How money bail perpetuates an endless cycle of poverty and jail time. Prison Policy Initiative. Web. Retrieved on February 23, 2021 from https://www.prisonpolicy.org/reports/incomejails.html

Red's Anytime Bail Bonds. (January 3, 2020). The Five Most Common Types of Bail. Red's Anytime Bail Bonds. Retrieved March 4, 2021 from https://www.cityofdenverbailbonds.com/2020/01/03/five-most-common-types-of-bail/

Rockett, Darcel. (March 7, 2019). Poor people often can't afford to pay bail- even when they're innocent. An app developed in Chicago offers help using your spare change. Chicago Tribune. Web. Retrieved March 4, 2021 from https://www.chicagotribune.com/lifestyles/ct-life-appolition-making-bail-20190124-story. $\underline{\mathrm{html}}$

Torgovnick, Kate. (August 21, 2018). How the bail system in the US became such a mess- and how it can be fixed. TED. Web. Retrieved on February 20, 2021 from 
https://ideas.ted.com/how-the-bail-system-in-the-us-became-such-a-mess-and-how-it-c an-be-fixed/

Wagner, Peter. (February, 2019). State of Phone Justice. Prison Policy Initiative. Web.

Retrieved on March 4, 2021 from

https://www.prisonpolicy.org/phones/state_of_phone_justice.html

Wealthsimple. (July 7, 2020). The Long-Term Economic Disaster of Cash Bail.

WealthSimple Magazine. Web. Retrieved on February 18, 2021 from

https://www.wealthsimple.com/en-ca/magazine/cash-bail

Wilson,Valerie. (February 22, 2018). Working harder or finding it harder to work.

Economic Policy Institute. Web. Retrieved on March 4, 2021 from

https://www.epi.org/publication/trends-in-work-hours-and-labor-market-disconnection/

Yang, Crystal. (November 2017). Toward an Optimal Bail System. New York University Law Review. Web. Retrieved on February 18, 2021 from

https://www.nyulawreview.org/issues/volume-92-number-5/toward-an-optimal-bail-syste

$\underline{\mathrm{m} /}$ 